\title{
Proceeding
}

Supplementary Issue: Spring Conferences of Sports Science. First International Conference in Iraq on Sport for Peace, 4 April 2019. Baghdad Science Institute, Baghdad, Iraq.

\section{Modelling the role of brand community on brand features through Mediation of brand attachment}

\author{
MEHDI RASTEGARI, SEYAD EHSAN AMIRHOSSINI , AHMAD TORKFAR \\ Department of Sport Management, Yasooj Branch, Islamic Azad University, Islamic Republic of Iran
}

\begin{abstract}
The purpose of this study was modelling the role of brand community on brand attributes through Mediation of brand attachment. The statistical population of the study consisted of customers of Iranian sports brands (Daei and Majid) and foreign (Adidas and Leaning) at Shiraz sport shops. According to Morgan's table, 388 people were selected randomly. A 29-item questionnaire was used in a five-point Likert scale. After a semistructured snowball interview with 15 elites and experts, and using Delphi technique to qualify the questionnaire and confirm its formal and content validity By professors and its internal reliability using Cronbach's alpha test. The statistical methods of factor analysis and structural equation modelling test were used. The findings of the research showed that fitting indices are desirable and indicate confirmation of the model. Therefore, it can be said that the brand community directly and significantly affects the brand's identification and brand identity and attachment with the brand through brand mediation on increasing commitment to the brand community. However, due to the effect of commitment to brand community on brand attachment and, indirectly, their high impact on brand commitment, as well as the identification and identification of brand identity and on commitment to brand community, we can deduce Demonstrating that brand identity has a direct impact on brand commitment and through brand attachment to brand commitment. Keywords: Brand community; Brand identity; Brand attachment; Brand commitment; Customers.
\end{abstract}

\section{Cite this article as:}

Rastegari, M., Amirhossini, S.E., \& Torkfar, A. (2019). Modelling the role of brand community on brand features through Mediation of brand attachment. Journal of Human Sport and Exercise, 14(4proc), S505-S515. doi:https://doi.org/10.14198/jhse.2019.14.Proc4.09

Corresponding author. Department of Sport Management, Yasooj Branch, Islamic Azad University, Islamic Republic of Iran. E-mail: amirhosseini474@gmail.com

Supplementary Issue: Spring Conferences of Sports Science. First International Conference in Iraq on Sport for Peace, 4 April 2019. Baghdad Science Institute, Baghdad, Iraq.

JOURNAL OF HUMAN SPORT \& EXERCISE ISSN 1988-5202

(c) Faculty of Education. University of Alicante

doi:10.14198/jhse.2019.14.Proc4.09 


\section{INTRODUCTION}

In Brand marketing is often the starting point, the distinction between products and services provided with products and services in competition, as it plays a crucial role in the success of organizations. Brand is one of the most important communication tools in the customer relationship management suite, which can act as a defensive tool for keeping current customers and an aggressive marketing tool to gain new customers. The importance of defensive marketing is determined by the fact that the cost of attracting a new customer is much higher than maintaining the same customer. Brand is valued for two reasons for customers: first, perceived risk of consumption decreases, and secondly, it saves on decision-making costs. Brand is an integral part of the company's value and is a strategic asset that can be regarded as a stimulus to the company's marketing planning process. This means that a brand can be considered as a competitive advantage for a company. Basically, consumers entertain a degree of doubts about the promise they have made and the willingness and ability to do so, and the advantage of maintaining a long-term relationship with the consumer service provider. Hence, companies have been motivated to make up for doubt, demonstrating a willingness to act on promises made to the client. Despite the fact that more than 30 years of continuous work has been done in terms of brand knowledge enrichment in Europe and the United States, this concept has not been taken into consideration in Iran. The lack of brand knowledge and the lack of proper brand management in Iran has had no result other than the increasing sales of foreign brands and the isolation of domestic products (Shams, 2008). Brand is one of the most important assets of every company that is the source of the highest value. According to the definition of the American Marketing Association, a brand is: a name, term, sign, sign, design or combination of all that is used to identify and distinguish the goods or services of a vendor or a group of vendors, and cause These goods and services are distinguished from other goods and services provided by competitors (Sultan Hosseini et al., 2017). Given the branding and branding opportunities for organizations and consumers, this issue has been heavily taken into account by marketers. Brand is a very practical strategy for distinguishing itself in the service and manufacturing industries. In today's world, companies and organizations not only seek to compete for market products but also have a great deal of effort to bring about the convergence of customer perceptions with themselves (product, brand, Inc.) Over the past decades, the value of a company was measured by real estate, then tangible assets, factories and equipment. However, today, economists have come to the conclusion that the true value of a company is somewhere outside of it, in the minds of potential buyers (Mudy et al., 2016). The price of a product measures its monetary value, but the brand introduces that product and reveals its distinctive features (Sultan Hosseini et al., 2017). A brand or a brand name brings loyalty to customers in a competitive market. Today, brand is an integral part of marketing strategy and brand marketing is at the heart of the business. The best known companies in the world, such as Procter \& Gamble and March, are structured around the brand community (Heidarizadeh et al., 2016). Sports brands are also at the centre of popular consumer brands and are the main driver of modern sports trade and an existing factor in contemporary world culture. That is, they display a real world language with their own words, codes, values, resources, and their representatives. Like some home appliance brands (for example, Philips), food products (like Dan one), or multi-media products (like Samsung), sports brands have been well integrated with people's lives. Nike has acquired almost a mythical position, one of the few globally popular brands that has the highest level of recognition among adolescents. Ultimately, Nike is considered as a trademark related to its product and product performance, as well as a symbolic value brand to promote its achievements and excellence. Nike has been praised all over the world. Like Adidas in the whole world, or in Logs tow in Europe, and many others, sports brands have shown that they are above all economic and industrial goals, and they are reallife issues. Many people show great acclaim for some sports brands, whether for corporate brands or clubs. Sports brands for some consumers are a privilege of social and everyday life, they often have a power of social expression, meaning freedom, life and power (Bachet et al., 2014). Companies have seen growing 
interest in brand communities over the last decade. The brand community is a concept related to consumerbrand relationship (such as attitude toward brand, brand personality, brand image) (Zhou et al., 2012). The brand community term $(\mathrm{BC})$ was first introduced by Albert Moniz and Thomas. A brand community can be developed as a group of consumers with common fortune and brand enthusiasm and a well-developed community identity whose members share their activities in pursuit of collective ends or expressing feelings and obligations Mutual Definition. A strong brand community can lead to established social loyalty and commitment to brand and even lead to brand loyalty. Therefore, the brand community is specialized because in the centre there is a product or service with a brand, and like other societies, it has three characteristics of common awareness, customs, traditions and moral responsibility. In fact, participants are making bigger brands with the brand and play a vital role in the brand's final legacy (Dubois \& Westerhausen, 2011). Brand societies have become a major issue considering the importance of marketing planning process and paying attention to brand equity and has become one of the most encouraging developments in marketing in recent years (Hur et al. , 2011). The brand community is a powerful phenomenon that has come to be seen across the globe and has brought many benefits to companies. By managing, protecting and protecting brand communities, companies can build loyalty in the customer, increase their marketing and brand productivity (Terechshenko \& Radionova, 2011). Commitment to the brand community is also comprised of two dimensions of emotional and computational dimensions that interact between the components of the relationship and the formation of loyalty to the mediator (Tsai, 2011). Customer commitment to brand name is a new concept and it is argued that as a result of the expected outcomes of the customer, the company's supply to the market, such as the consequences of buying a product, the sense of identity with the brand, etc., is affected. Take place According to (Moorman et al. ,1992), customer commitment is a kind of attitude or sustainable desire to a company or brand name. The extent to which customers as members of an organization are psychologically dependent on an organization, name, brand or its products, and their relationship with the organization is strengthened by the continuous desire to maintain membership. Commitment is an attitude and a mental state that reflects the desire, the need and the requirement to continue working in an organization. In the meantime, desire means the previous person's desire to continue working in the organization, and the need for it means that one has to continue to serve in the organization for the investments made in the organization. Consumers have a similar relationship to the relationship that they make in their personal lives with others, with some trade names (Each et al., 2006). This relationship can have the cognitive benefits of satisfaction and trust in the trade name and the emotional attachment to a different brand name and lead to the formation of a strong link between the consumer and the brand name (Fournier \& Yao, 1997 ). The concept of attachment is a trademark of psychological studies in the field of attachment to material possessions (Belaid \& Behi, 2010). Researchers have defined brand affinity as a special and specific form of relationship between a person and a given material asset, which requires a far greater ownership of a physical possession. For each brand, based on the basic needs of the customer, three dimensions are considered: the functional, symbolic, and empirical concept. The functional concept of a brand embodies the primary and apparent purpose of product creation and to address a need or a problem. The symbolic meaning of the brand relates to brands that satisfy the inner needs of individuals, including self-esteem, self-knowledge, and membership in a particular group. Ultimately, the brand's empirical concept implies estimating the needs of emotional pleasure, variety, or cognitive stimulation. According to research, the Nike brand has the following perceived value among consumers. Branding in the field of sport does not mean success and attraction of income and capital, but the creation of successful methods in attracting customers and creating strong brand identity will lead to the success and advance of the goals of the brands. One of the influential factors in sports brands' customers is the social identity of the winner. Brands can help consumers achieve their identity goals for symbolic meanings. For this reason, it can be argued that by understanding the concepts of brand identity, the knowledge of brand management could be richer and more comprehensive (Kuenzel \& Halliday, 2008). If a company wants to create a lasting image of its own, then it 
must first create its identity, then, based on this identity, it will make its message and image. Different research has been done about brand communities and their characteristics by choosing a variety of brands. Communities tend to be identified based on the identification and recognition of their members. (Algesheimer et al. ,2005) argues that the power of consumer interactions with the community as the main source of its core determines that the members can be different. But only in this dimension, unlike other identities that a person may be unique and separate, it is a collective or shared identity. Brand communities can become an important marketing opportunity. Communities with clear links to that brand are involved. In other words, one of the relationships of community members is explicitly with the brand (Tamson, 2016). In research identifying and identifying a society as its perception of the actual or symbolic adherence of a person to a defined group, while (Laroche et al. ,2012) divided this variable into three parts. Cognitive element (membership awareness), evaluation (positive or negative reasons for membership in the group) and emotional component (commitment to the group). In this regard, (Kuenzel \& Halliday ,2008) research identifies and identifies a strong affiliate or affinity with a brand. Individuals with brands that enhance their identity are identified. In the research of (Algesheimer et al. ,2005), identifying and identifying a brand leads to identifying and identifying a brand, and the inverse relationship between them is also shown. Also, in (Bagozzi \& Dholakia,2010), identifying and identifying a brand community has a direct and positive impact on identification and brand identification. The findings of these two researchers show that there is a two-way relationship between identifying and identifying the brand community and identifying and identifying a brand (Zhou et al., 2012). In this regard, companies are taking steps to manage relationships with their customers. One of the operational goals of any organization or sports organization is to implement policies to attract and retain customers, and this poses one of the challenges facing us in terms of earning and raising long-term profits. But despite the importance of brands in the sports sector, little research has been conducted on brand communities in Iran and abroad. Hence, research is needed to build brand communities, manage them, and explore the role of societies in the commitment and loyalty of customers and their impact on identifying needs and producing new products and services. Creating a customer base is a major and important task for consumers who are strongly committed to the brand, but also a challenging task for marketers and executives who are faced with (Carlson, 2015). With regard to the marketing planning process and brand equity, the brand community is a very important factor and has become one of the most encouraging developments in marketing in recent years. In recent years, there has been a lot of research in this direction, but there has not been much research on sports brands. Considering the above explanations and considering that the variables studied in this research are not simultaneously studied in any research, and the necessity of its review in a new statistical society such as the Shiraz metropolis as new and new aspects of the research It is a stimulus for choosing this topic for research. Therefore, considering that the brand and its components and variables are among the most recent ones in the field of research, and given the fact that in recent years the impact of brand communities on marketing performance has been studied, but about the effects of a community Brand on brand features, fewer research has been done empirically. Therefore, considering the benefits and benefits that companies can make by building a strong brand community, and the effects of brand attributes on company performance, the research question is how the brand community interacts with brand affiliation on brand attributes Does sports affect?

\section{RESEARCH METHODOLOGY}

The method of this research is applied and in terms of the possibility of controlling the variables, the type of research is non-experimental and the type of research is descriptive - correlation. The statistical population of this study was Iranian and foreign sports brands (among Iranian brands of two active brands; Daei, Majid and foreign brands of two brands: Adidas and Lening at the level of sports stores in Shiraz. In order to determine the sample size, 384 people were estimated by Morgan table due to the uncertain number of 
consumers. Considering the probability of falling samples, the researcher distributed 400 questionnaires among the target customers of the brands and finally returned 388 acceptable questionnaires. The sample size in this study was 388 , which was done by random sampling. The instrument was a 29 -item questionnaire on Likert scale. In order to identify and determine the identity of the community, from six questions designed (Algsheimer et al., 2005), to assess the commitment to the brand community, from the 5 questions related to, ten questions related to the intermediary variable of the research The brand-related component of the brand (Tamson, 2016), five questions related to the identification and brand identification variable (Zhou et al., 2012), and, finally, three questions about the brand commitment variable belonging to. To assess the factual and content validity of the questionnaire, some of the sports management professors were examined and then the questionnaire was distributed among the community. The results of this study were analysed using structural equation modelling with PLS method. Reliability and structural validity using the ELS algorithm are presented in Table 1.

\section{RESEARCH FINDINGS}

\section{Exterior Model Assessment}

In order to measure the external model, the combination of reliability, Cronbach's alpha and convergence validity (mean extracted variance) are investigated. Combined reliability is the internal correlation of the variables observed by each hidden variable. Cronbach's alpha expresses the ability of questions to accurately explain their dimensions to an expression of the internal consistency of observable variables. Also, convergence validity refers to the ability of one-dimensional indicators to explain that dimension. Results are presented in Table (1).

Table 1. Exterior Model Assessment

\begin{tabular}{|l|c|c|c|}
\hline The variable is now & AVE & CR & á \\
\hline Identify and identify the brand community & $0 / 47$ & $0 / 84$ & $0 / 77$ \\
\hline Commitment to the brand community & $0 / 43$ & $0 / 79$ & $0 / 67$ \\
\hline Brand attachment & $0 / 43$ & $0 / 88$ & $0 / 85$ \\
\hline Identification and brand identity & $0 / 43$ & $0 / 780$ & $0 / 66$ \\
\hline Commitment to brand & $0 / 63$ & $0 / 83$ & $0 / 70$ \\
\hline
\end{tabular}

As shown in Table 1, all variables have high reliability in the model. Combined reliability and Cronbach's alpha higher than 0.7 demonstrate the acceptability of the reliability of each structure. Also, the criterion value for the acceptance level is the convergence validity of 0.4 . As shown in the table above, the AVE values for each construct are more than 0.4 , and this suggests that the convergence validity of the current questionnaire is acceptable. 


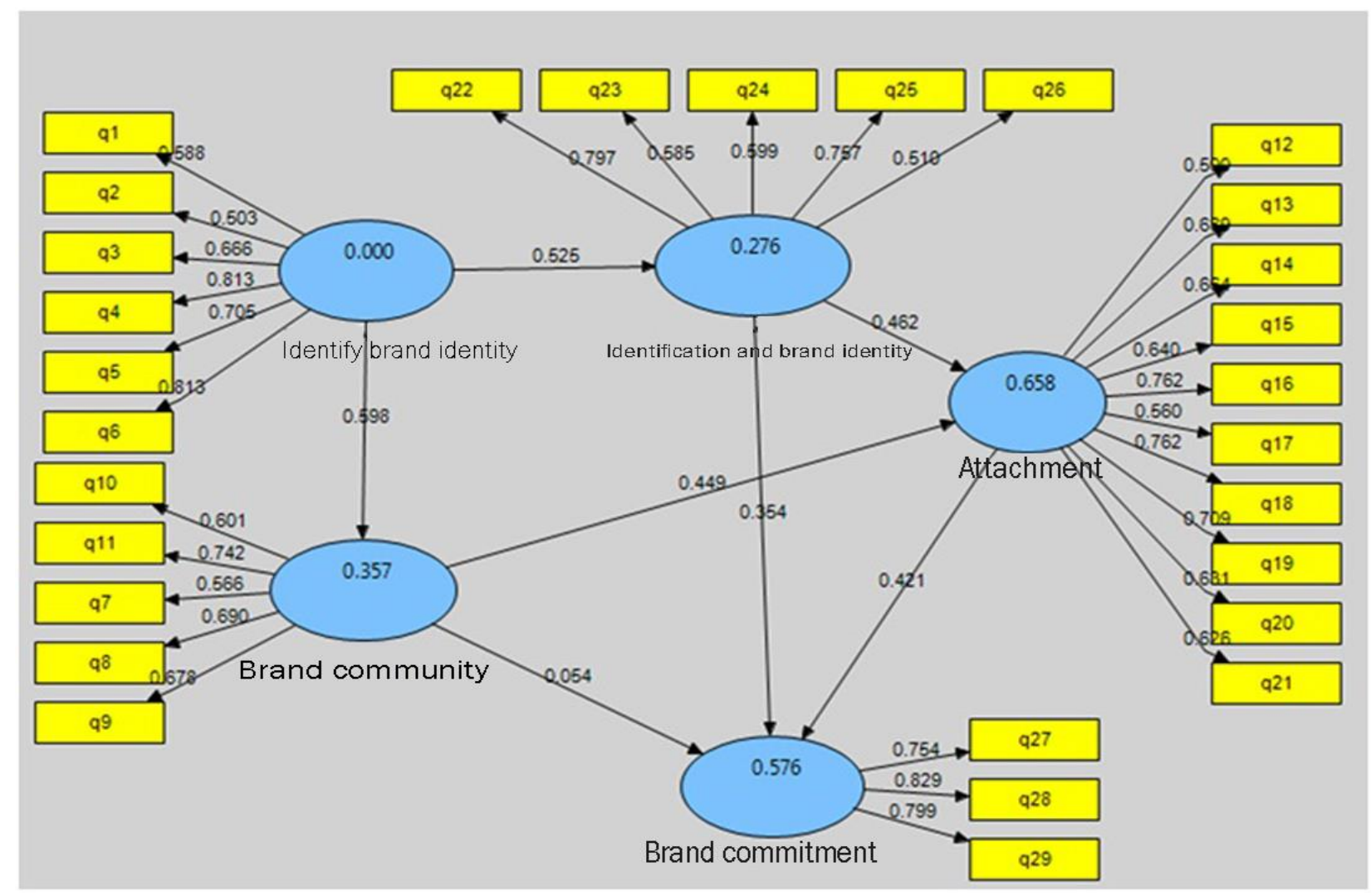

Figure 1. PC software output in standard model

According to Fig. 1, the value of R2 for the anecdotal structure of the attachment of 0.658 , the brand commitment structure of 0.576 , the endogenous structure of identification and brand identity were 0.276 and for the internal structure of the commitment to the brand community was calculated to be 0.357 . Considering the three values of the criterion, the appropriateness of fitting the structural model is confirmed. The calculation of the cohen $\mathrm{f} 2$ intensity is calculated from the following equation:

$$
\text { F2 }=(\text { R2Included }- \text { R2 Excluded })(1-\text { R2 Included })
$$

According to the results, the calculated value of $f 2$ for the identification and brand identification line was brand commitment 0.02 ; identifying and identifying brand to brand attachment 0.38 ; attachment path to brand and brand commitment 0.11 ; commitment path to brand community to commitment The brand 0.0 and the commitment path to the brand community have been calculated as brand attachment 0.38 . On the route No. 2,3 , and 5 , the size of the impact was large and for routes No. 1 and No. 4 were positive, but the size had a small effect. According to the algorithm, several criteria are used to examine the fit of the structural model of the research; the first and most basic criterion is the Z-values of the t-values (meaningful state). The brand's commitment to Brand Commitment was lower due to the low level in the range of 1.96, indicating a rejection of this relationship between the two variables, and in other directions, a positive and significant relationship was established. To study the overall quality of the model in the least squares, we use the GOF index, which. The fitting above the model shows that this model is well explained by partial least squares. Goodness index fit between zero and one and identified three values of $0.01,0.25$ and 0.36 as weak, moderate and strong values for GOF, respectively. The calculation of the overall quality of the model is obtained from the following equation: 


$$
\text { GOF }=\sqrt{\overline{\text { Communality }} \times \overline{\mathrm{R} 2}}=0 / 473
$$

Since the value Q2 of the internal structure of attachment is 0.65 , brand commitment of 0.36 , commitment to the brand community is 0.15 , and the endogenous structure of identification and brand identity is 0.11 , it shows strong predictive power The model relies on these structures and reaffirms the fit for the structural model of the research. Also, according to the validation indices of the variables, hidden variables showed that all variables are positive, which indicates the quality of the desired measurement model.

In general, according to the final output of the software, and its fitting indexes, it was found that the proposed model is consistent with the data obtained from the research. Therefore, we can say that the conceptual model of research is based on what has been obtained.

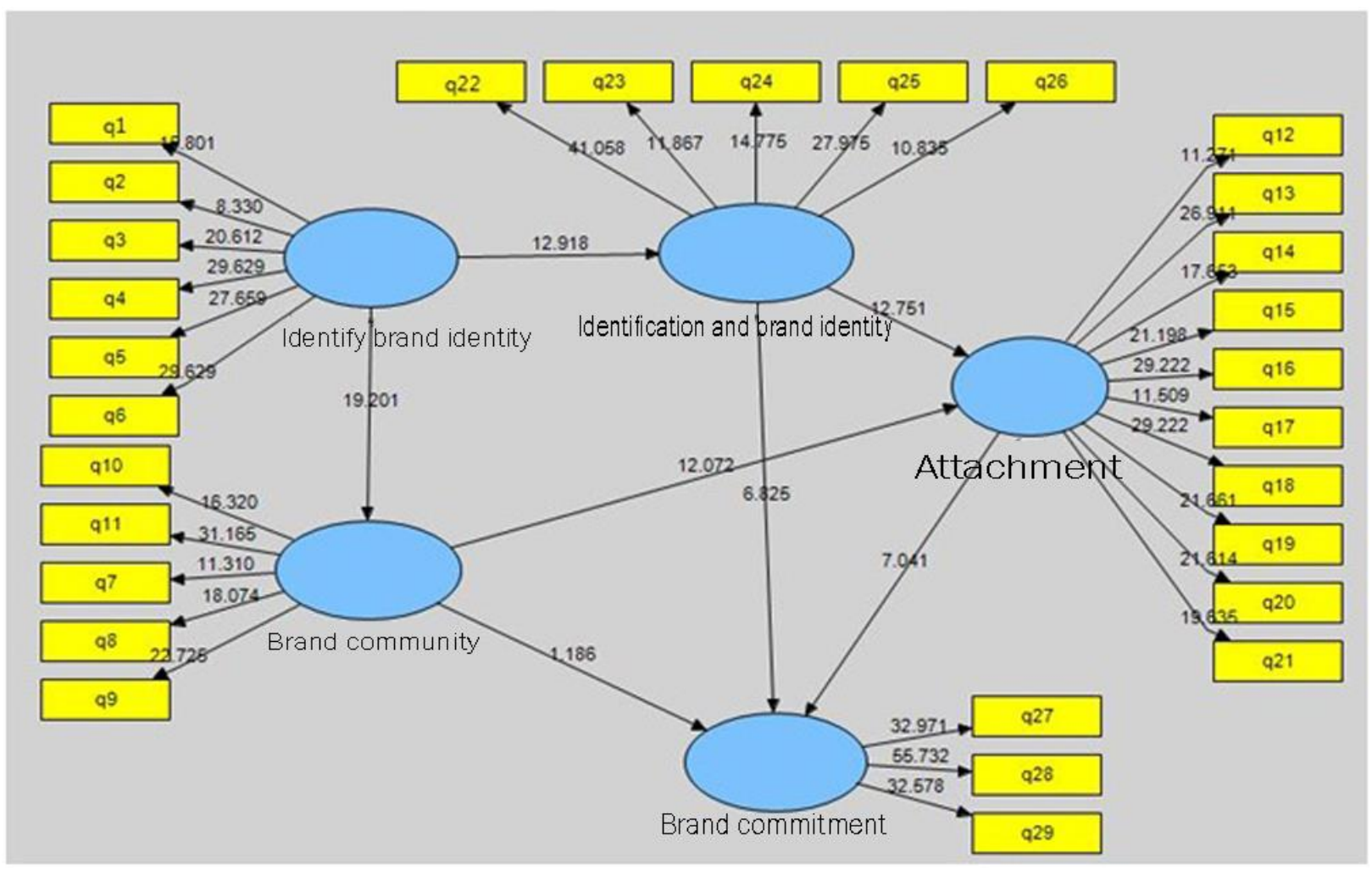

Figure 2. PLS software output in a meaningful state

Regarding the results of Table 2, the effect that identification and brand identification on brand commitment indirectly and through the mediating factor of attachment to brand commitment is $0.20 \%$, and the indirect effect of the commitment path to brand community on commitment to The brand has been calculated to be 0.189 . In other words, the variable of variable attachment identifies and defines brand identity and brand commitment to brand commitment positively. 
Table 2. Direct and indirect effects of the final research model

\begin{tabular}{|l|c|c|c|}
\hline Relationships & $\begin{array}{c}\text { Direct } \\
\text { effect }\end{array}$ & $\begin{array}{c}\text { Indirect } \\
\text { effect }\end{array}$ & $\begin{array}{c}\text { Whole } \\
\text { effect }\end{array}$ \\
\hline $\begin{array}{l}\text { Identification and identity of the brand community to identify and } \\
\text { identify brand identity }\end{array}$ & $0 / 52$ & & $0 / 52$ \\
\hline $\begin{array}{l}\text { The path to identification and brand identity is a commitment to } \\
\text { the brand community }\end{array}$ & $0 / 35$ & & $0 / 35$ \\
\hline Identification and Brand Identity Brand Brand Approach & $0 / 36$ & $0 / 20$ & $0 / 54$ \\
\hline The attachment path to brand commitment & $0 / 42$ & & $0 / 42$ \\
\hline Brand Commitment Commitment to Brand Commitment & $0 / 054$ & $0 / 189$ & $0 / 24$ \\
\hline Commitment Brand Commitment to Brand & $0 / 44$ & & $0 / 44$ \\
\hline Identification and Brand Identity Tracking Approach to Brand & $0 / 46$ & & $0 / 46$ \\
\hline
\end{tabular}

\section{Extracted Model from the sports garment industry}

The results of the research hypothesis showed that commitment to the brand community in Shiraz sports apparel industry was not satisfactory, and also the moderating variable of the similarity of the brand community in the sports garment showed a positive relationship between commitment to the brand community and brand affection. And acceptable (it should be noted that considering the fact that the commitment to the brand community was not an acceptable path to brand commitment, so the moderate effect on it was significant, but the conceptual model extracted from the research was eliminated). The extracted model of the researchers is presented at the end as follows.

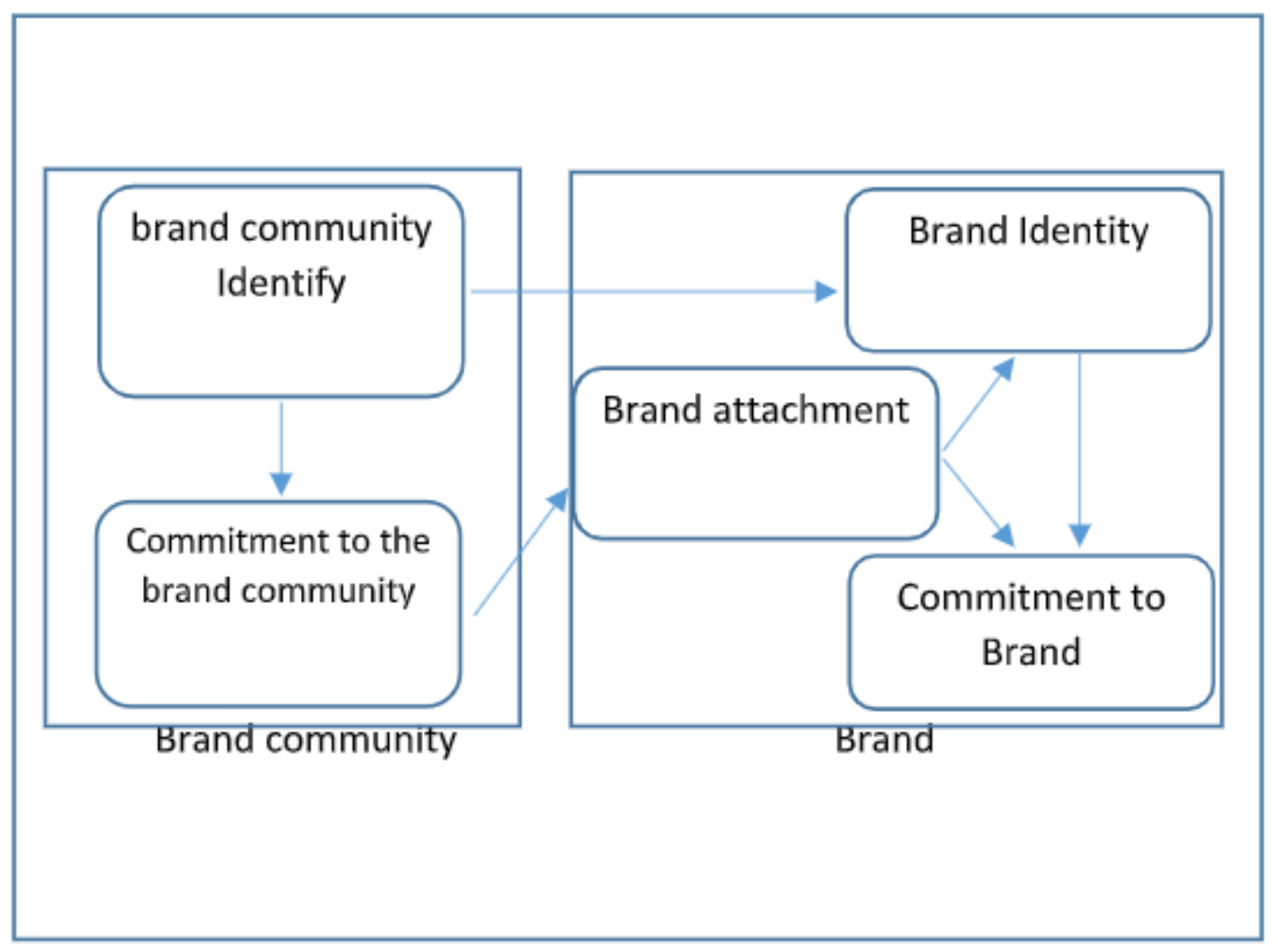

Figure 3. Conceptual model extracted 


\section{DISCUSSION AND CONCLUSION}

Brand communities are tools that help strengthen brand and consumer relationships. A brand community can be developed as a group of consumers with common fortune and brand enthusiasm and a good community identity whose members are jointly involved in their activities to accomplish collective goals or express mutual feelings and commitments. The purpose of this research was to model the role of brand community on brand features by mediating brand attachment in the domestic and foreign apparel industry. Considering the value of R2 for the anecdotal structure of the attachment of 0.658 , the brand commitment structure of 0.576 , the identifier of the brand structure and brand identity were 0.276 and for the internal structure of the commitment to the brand community, it was calculated to be 0.377 , which according to the three values of the criterion , Approves the suitability of fitting the structural model. According to the results, the calculated f2 value for the corresponding paths indicated the magnitude of the positive effect of the paths in question. The overall quality index of the model or index GOF 0.473 was calculated to validate fit for the structural model at the first stage of the re-analysis. Also, Q2 value of the internal structure of attachment was 0.65 , brand commitment was 0.36 , commitment to brand community was 0.15 , and internal structure was identified and brand identity was calculated to be 0.11 , indicating the strong predictive power of the model regarding It has structures and reaffirms fit for the structural model of research. The findings of this study are consistent with the results of other studies, such that, (Zhou et al. ,2012), (Bagozzi \& Dholakia,2010) and (Algesheimer et al. ,2005) also validated these results in part of their research. Therefore, the existence of a positive relationship between identifying and identifying the brand community by identifying and identifying a brand indicates that brand identity increases with the identification and identity of the brand community. Therefore, the customer has chosen sports brands to shape his identity and always wants to support the brand; in other words, by increasing the identification and identity of the brand community, commitment to the brand community also increases. This result is similar to the research, (Kuenzel \& Halliday ,2008),. Therefore, consumers who commit to a brand community have a psychological or emotional attachment to the brand, indicating a degree that makes brandy the only acceptable choice in a particular category of products. As a whole, a customer is attracted to a strong brand community, as well as a brand identity, which shapes the attachment of brand commitment to the customer. In the case of indirect effects, the brand attachment variable also mediates the relationship between commitment to the brand community and the brand commitment variable positively (0.127). Also, the brand attachment variable mediates the relationship between identification and brand identity and brand commitment positively (0.123). Therefore, it can be acknowledged that the commitment to the club of sports brands by affinity with the brand affects brand commitment, which means that brand attachment helps the customer in a long-term relationship with the customer's club in interacting with other Members and the use of services and activities in the brand community will always choose brand use and close relationships with other members in the customer community will lead to its commitment to the brand. Consumers committed to the brand community find a deep and positive brand and a strong attachment to the brand community. Accordingly, it can be said that brand attachment has a significant relationship with brand commitment, which means that brand attachment also helps loyal and committed committed customer to the brand community, and that positive word-of-mouth advertisements are made by the customer. He even has a tendency to repeatedly select a brand and choose from a variety of brands to choose from. Therefore, it can be concluded that the commitment to the sports brands through affiliation with sports brands affects the commitment to sports brands. Then it can be said that after identifying and recognizing the brand from customers, real attachment and dependency are created, which causes the emotional bond between the brand and the image of the consumer. Therefore, when customers show brand attachment, the customer is committed to brand loyalty and commitment through brand affiliation. Brand attachment leads to a relationship between identifying brand identity and brand commitment. So it can be concluded that identifying and identifying brand affects brand commitment through brand affinity. Combining the results of research 
with people such as. Therefore, the total of these researches shows the importance of the brand community in the business environment and in particular the sports brands' societies. Therefore, it is understood that the brand is an integral part of the sports marketing strategy and marketing of brands is at the heart of the business. Identify brand management through the management of brand relationships. Many marketers in the current marketing environment believe that brand communities are cost-effective and powerful. Based on the results of this research and given the increasing competition between sports brands and the challenge of attracting new customers and maintaining current customers, to create a brand community in such a competitive environment, sports brands should seek to build and strengthen their brand features in Customer perceptions and the implementation of the strategies required in this area. The brand community is a powerful phenomenon that has emerged around the world and has brought many benefits to companies. Creating a customer base that is highly committed to the brand is a major and important challenge at the same time facing marketers and executives in today's competitive world. By managing, protecting and protecting brand communities, companies can shape attachment and loyalty to the customer, increase their marketing and brand efficiency. The brand community is also emerging through customer experience over the years. Therefore, in general, it is clear that the brand community directly and significantly affects the identification, brand identity and brand affinity, and by affixing brand affirmation on the increase in commitment to the brand community. However, due to the effect of commitment to brand community on brand attachment and, indirectly, their high impact on brand commitment, as well as the identification and brand identity and brand identity, it can be deduced from the commitment to the brand community. Brand identity has a direct impact on brand commitment and through brand commitment to brand commitment. This evidence suggests that a successful sports brand community, if perceived by clients, is more attractive and more influential. Creating a positive mindset in customer perceptions also occurs when a brand community is popular with customers based on purchasing and satisfaction, and only having an identity and commitment to the brand community will not be effective to create a positive change.

\section{REFERENCES}

Shams, Rahil (2008), Investigating the Relationship Between Marketing Activities and Brand Creation Values Using the Acer Extended Model, Proceedings of the Third International Brand Conference, pp. 43-61.

Sultan Hosseini, Mohammad, Nasr Esfahani, Davood, Javani, Vajihe and Salimi, Mehdi (2017), Determination of relative share of brand loyalty to brand association among fans of Iranian Football League, Sport Management Journal, Volume 3, Issue 9.

Mudy, Davood; Mirkazemi, Seyedeh Ozra and Vahdani, Mohsen (2016), Relationship between Brand Features and Brand Loyalty in Sport Shoes, Contemporary Research in Sport Management, 5 (9), 61-71.

Heidarizadeh, Kambiz; Alwani, Seyyed Mahdi and Qalandari, Kamal (2010), A Study on the Impact of Brand Social Power Based on Levels of Customers' Mental Readiness on Purchasing Decision, Future Studies in Management (Management Research), Autumn 2010, Volume 21, Issue 86, 5227.

Bachett, Patrick, Hilaryt, Dieter, Buddot, Guillermo (2014). Sports brands, Translation: Commercial, Farshad, Nasr Esfahani, Davood; Majedi, Nima. Hatami Publications, p. 9.

Zhou, Zh. Zhang, Q., Su, Ch. \& Zhou, N. (2012). How do brand communities generate brand relationships? Intermediate mechanisms. Journal of Business Research, 65(2012): 890-895. https://doi.org/10.1016/i.jbusres.2011.06.034 
Dubois, T. \& Westerhausen, U. (2011). Brand loyalty creation within online brand communities. Marketing Communications Managrment, Thesis of Copenhagen Business School, Department of Marketing, Characterrs: 234.787, Submission October 2011.

Hur, W.M., Ahn, K.H. \& Kim, M. (2011). Building brand loyalty through managing brand community commitment. Management Decision, 49(7): 1194-1213. https://doi.org/10.1108/002517411111151217

Terechshenko, M. \& Radionova, V. (2011). Brand communities: A quantitative study of brand community influence on prospective and existing members, Thesis. Ume o University. Faculty of Social Sciences. Ume • School of Business.

Tsai, S.P. (2011). Fostering international brand loyalty through committed and attached relationships. International Business Review, 40, pp. 300-12. https://doi.org/10.1016/i.ibusrev.2010.10.001

Moorman, C., Zaltman, G., \& Deshpande, R. (1992). Relationships between providers and users of market research: The dynamics of trust. Journal of marketing research, 29(3), 314-328. https://doi.org/10.1177/002224379202900303

Each, F. R., Langner, T., Schmitt, B. H., \& Geus, P. (2006). Are brands forever? How brand knowledge and relationships affect current and future purchases. Journal of Product \& Brand Management, 15(2), 98-105. https://doi.org/10.1108/10610420610658938

Fournier, S., \& Yao, J. L. (1997). Reviving brand loyalty: A reconceptualization within the framework of consumer-brand relationships. International Journal of research in Marketing, 14(5), 451-472. https://doi.org/10.1016/s0167-8116(97)00021-9

Belaid, S., \& Temessek Behi, A. (2011). The role of attachment in building consumer-brand relationships: an empirical investigation in the utilitarian consumption context. Journal of Product \& Brand Management, 20(1), 37-47. https://doi.org/10.1108/10610421111108003

Kuenzel, S., \& Halliday, S. V. (2008). Investigating antecedents and consequences of brand identification. Journal of Product \& Brand Management, 17(5), 293 - 304. https://doi.org/10.1108/10610420810896059

Algesheimer, R., Dholakia, U.M. \& Herrmann, A. (2005). The social influence of brand community: Evidence from Eropean Car Clubs. J Mark; 69(3): 19-34. https://doi.org/10.1509/jmkg.69.3.19.66363

Tamson (2016) "The Impact of Brand Identity on Brand Commitment and Attachment in Sporting Goods Consumers" The Role of Consumer- Brand identification. Paper presented at the European Marketing Academy 45th Anuual Conference Istanbul.

Laroche, M., Habibi, M., Richard, M.O. \& Sankaranarayanan, R. (2012). The effects of social media based brand communities on brand community markers, value creation practices, and brand trust and brand loyalty. Computers in Human Behavior, 28 (5): 1755-1767. https://doi.org/10.1016/i.chb.2012.04.016

Bagozzi, R.P. \& Dholakia, U.M. (2010). Antecedents and purchase consequences of customer participation in small group brand communities. International Journal of Research in Marketing, 23: 45-61. https://doi.org/10.1016/i.jiresmar.2006.01.005

Carlson, B.D., Suter, T.A. \& Brown, T.J. (2008). Social versus psychological brand community: The role of psychological sense of brand community. Journal of Business Research, 61: 284-291. https://doi.org/10.1016/j.jbusres.2007.06.022

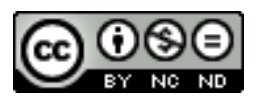

This work is licensed under a Attribution-NonCommercial-NoDerivatives 4.0 International (CC BY-NC-ND 4.0). 